\title{
Mixed adeno(neuro)endocrine carcinoma arising from the ectopic gastric mucosa of the upper thoracic esophagus
}

\author{
Toshihiro Kitajima ${ }^{1 *}$, Sachiko Kaida', Seigi Lee ${ }^{1}$, Shusuke Haruta ${ }^{1}$, Hisashi Shinohara', Masaki Ueno', \\ Koichi Suyama ${ }^{2}$, Yasunori Oota ${ }^{3}$, Takeshi Fujii ${ }^{3}$ and Harushi Udagawa ${ }^{1}$
}

\begin{abstract}
We report a case of mixed adenoendocrine carcinoma of the upper thoracic esophagus arising from ectopic gastric mucosa. A 64-year-old man who had been diagnosed with an esophageal tumor on the basis of esophagoscopy was referred to our hospital. Upper gastrointestinal endoscopy revealed the presence of ectopic gastric mucosa and an adjacent pedunculated lesion located on the posterior wall of the upper thoracic esophagus. Subtotal esophagectomy with three-field lymph node dissection was performed. A microscopic examination revealed that there was a partially intermingling component of neuroendocrine carcinoma adjacent to a tubular adenocarcinoma which was conterminous with the area of the ectopic gastric mucosa. Although the tubular adenocarcinoma was confined to the mucosa and submucosa, the neuroendocrine carcinoma had invaded the submucosaand there was vascular permeation. Each component accounted for 30\% or more of the tumor, so the final histopathological diagnosis was mixed adenoendocrine carcinoma of the upper thoracic esophagus arising from ectopic gastric mucosa. Adjuvant chemotherapy was not performed, because the postoperative tumor stage was IA. The patient was well and had no evidence of recurrence 16 months after surgery.
\end{abstract}

Keywords: Adenocarcinoma, Ectopic gastric mucosa, Esophagus, Mixed adenoendocrine carcinoma

\section{Background}

Most esophageal carcinomas are squamous cell carcinomas or adenocarcinomas arising from Barrett's epithelium, whereas adenocarcinomas derived from the esophageal glands or ectopic gastric mucosa (EGM)are rare. These cases arise mostly in the cervical or upper thoracic esophagus [1]. Moreover, gastrointestinal tumors displaying both exocrine and neuroendocrine differentiation are uncommon. To the best of our knowledge, esophageal mixed adenoneuroendocrine carcinoma (MANEC) [2] arising from EGM is extremely rare. We report a case of MANEC in the upper thoracic esophagus arising from EGM and also provide a review of the pertinent literature.

\section{Case presentation}

A 64-year-old Japanese man who had been diagnosed with an esophageal tumor during a screening esophagoscopy

\footnotetext{
* Correspondence: t.kitajima0407@gmail.com

'Department of Digestive Surgery, Toranomon Hospital, Tokyo, Japan

Full list of author information is available at the end of the article
}

was referred to our hospital. He had a history of Miles operation for rectal cancer 11 years earlier and partial hepatectomy and right lateral lymph node dissection for metastasis from rectal cancer 6 years prior to his presentation at our hospital. He had been smoking 20 cigarettes per day since his 20 s, consumed alcohol only on social occasions and was not a regular habitual drinker. A laboratory analysis showed no abnormalities in any parameters, including the levels of tumor markers such as squamous cell carcinoma antigen, carcinoembryonic antigen and carbohydrate antigen 19-9 (CA 19-9). An upper gastrointestinal endoscopy demonstrated EGM 19 to $21 \mathrm{~cm}$ distal from the incisors (Figure 1a) and a pedunculated lesion located on the posterior wall of the upper thoracic esophagus 21 to $23 \mathrm{~cm}$ distal from the incisors (Figure 1b), which was adjacent to the area of the EGM. A biopsy taken from the pedunculated lesion revealed well-differentiated tubular adenocarcinoma. Endoscopic ultrasound revealed that the tumor had invaded the submucosa. Computed tomography detected abnormal thickening at the posterior wall 


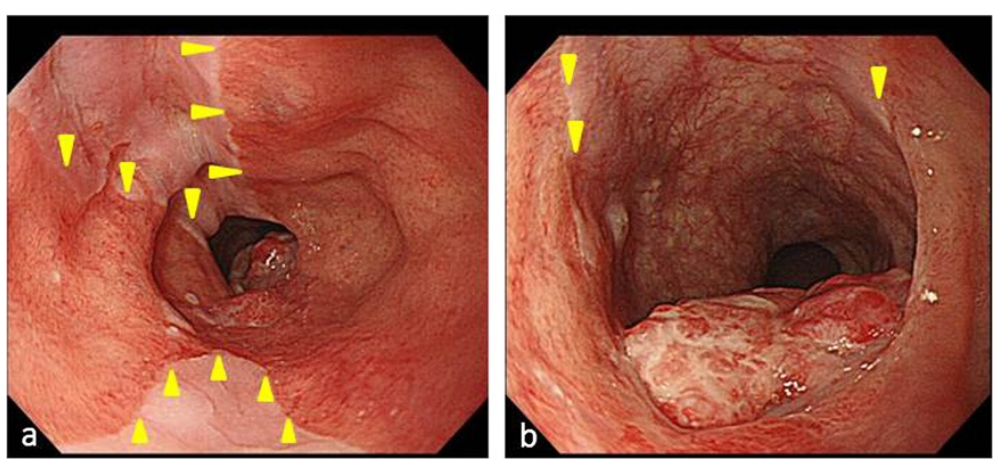

Figure 1 Upper gastrointestinal endoscopic findings regarding the pedunculated tumor. (a) Endoscopy revealed ectopic gastric mucosa 19 to $21 \mathrm{~cm}$ distal from the incisors on the oral side of the pedunculated tumor (arrowheads). (b) A pedunculated lesion was located on the posterior wall of the upper thoracic esophagus 21 to $23 \mathrm{~cm}$ distal from the incisors, adjacent to the area of ectopic gastric mucosa (arrowheads).

of the upper thoracic esophagus without any metastases to the lymph nodes or other organs.

The patient was diagnosed with primary adenocarcinoma arising from EGM in the upper thoracic esophagus. He underwent radical esophagectomy with three-field lymphadenectomy. Surgical reconstruction was performed through the posterior mediastinal route using a gastric conduit, followed by esophagogastrostomy through a cervical incision. Grossly, the pedunculated tumor, which measured $17 \times 15 \mathrm{~mm}$ (area within the red outline in Figure 2) was seen adjacent to a rough area $36 \times 30 \mathrm{~mm}$ in size (areas within white outlines in Figure 2). Histopathologically, the pedunculated tumor consisted of welldifferentiated tubular adenocarcinomaconfined within the submucosa (Figure 3a and e). The adjacent solid and trabecular component (corresponding to the area within the yellow outline in Figure 2) was composed of tumor cells showing elongated hyperchromatic nuclei and scant cytoplasm (Figure 3a and c), which were immunoreactive for CD56 (Figure 3b) and synaptophysin, confirming the diagnosis of neuroendocrine carcinoma (NEC). Additionally, vascular permeation of NEC was seen in the submucosal vein (Figure 3a, arrow). There was a histological transition between the NEC and tubular adenocarcinoma (Figure 3d), and the area of adenocarcinoma was conterminous with the EGM (corresponding to the area within the white outlines in Figure 2). The NEC and adenocarcinoma components accounted for at least $30 \%$ of the tumor lesion, respectively, confirming the diagnosis of MANEC. None of the 79 lymph nodes widely dissected, as was defined in our previous report [3], had metastases, and no lymphatic invasion was noted. The patient was diagnosed with stage

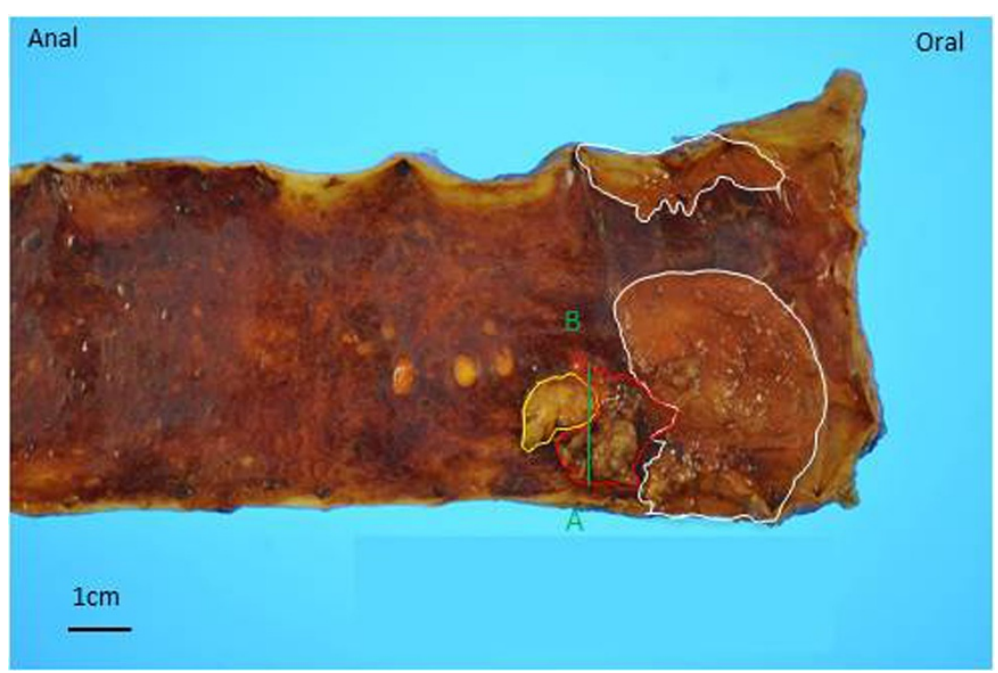

Figure 2 Gross findings of the resected specimen. The pedunculated tumor, which measured $17 \times 15 \mathrm{~mm}$, is indicated within the red outline adjacent to a rough area $36 \times 30 \mathrm{~mm}$ in size, which is indicated within the white outlines. The area within the yellow outline was composed of neuroendocrine carcinoma. The relationship between the NEC and adenocarcinoma components was confirmed on the green line in Figure 3. 


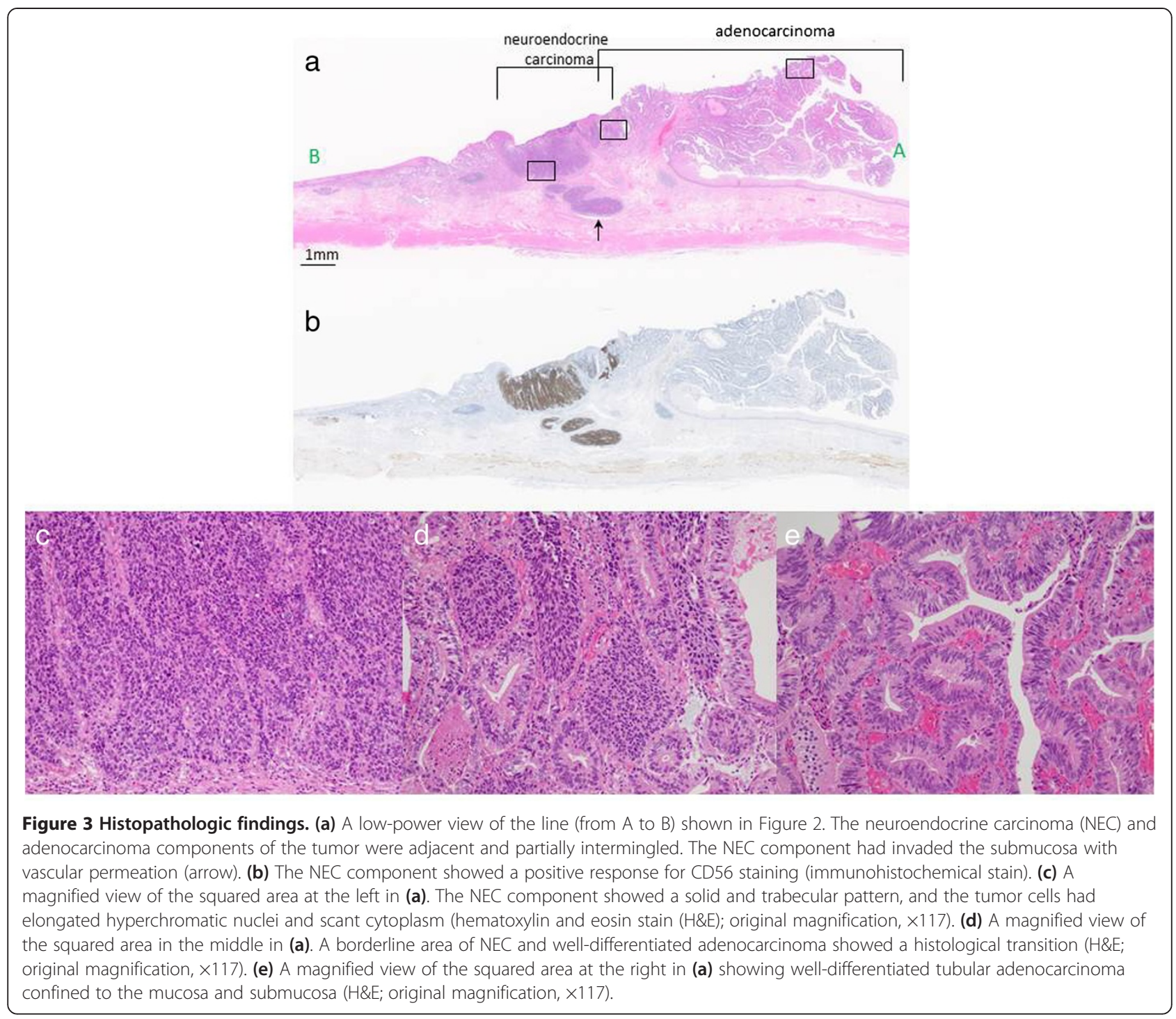

IA (pT1bN0M0) disease according to the edition of the American Joint Committee on Cancer and the International Union Against Cancer TNM classification system [4]. Postoperatively, bilateral recurrent laryngeal nerve injury was noted, and a tracheostomy was placed. Six months after the surgery, resection of the pyloric ring and diversion of the gastric conduit was performed in a Rouxen-Y fashion to prevent repetitive aspiration of regurgitant. For these reasons, it took approximately 8 months for the patient to safely resume oral intake. At the time of this writing, the patient has been doing well for 16 months, with no evidence of recurrence.

\section{Discussion}

Adenocarcinoma of the esophagus originates mostly from Barrett's epithelium in the lower esophagus. Primary adenocarcinoma of the cervical and upper thoracic esophagus is rare and is considered to be derived from the esophageal glands (mucosal or submucosal) or from EGM [1]. The reported incidence of adenocarcinoma in the upper esophagus has been found to account for only $1 \%$ to $2 \%$ of all malignant esophageal tumors [5], and 33 cases of adenocarcinoma derived from EGM have been described worldwide in the published literature to date (Table 1). Among the 2,237 surgical cases of esophageal cancer in our hospital during the past 40 years, only 2 were primary adenocarcinomas arising from EGM. EGM often occurs in the upper esophagus. Its incidence has been reported to range from $2 \%$ to $14 \%$, but these data have been increasing due to developments in endoscopic technology [6]. Although most patients with EGM are asymptomatic, some develop symptoms based on acid secretion from the EGM, such as dysphagia or a sore throat. Furthermore, EGM is sometimes accompanied by 
Table 1 Summary of esophageal adenocarcinomas arising from ectopic gastric mucosa published in the literature $(N=34)^{a}$

\begin{tabular}{|c|c|c|c|c|c|c|c|c|}
\hline Case & Reference & Year & Age & Sex & Histology & TNM & Treatment & Postoperative course \\
\hline 1 & Carrie [8] & 1950 & 64 & M & Adenocarcinoma & PT2NXMO & Resection of the upper esophagus & No recurrence $(>1 \mathrm{yr})$ \\
\hline 2 & Morson and Belcher [9] & 1952 & 56 & M & Adenocarcinoma & pT3N1M0 & Esophagectomy & Unknown \\
\hline 3 & Raphael et al. [10] & 1966 & 69 & M & Well- differentiated adenocarcinoma & unknown & Radiotherapy & Died (suicide) (2 mo) \\
\hline 4 & Davis et al. [11] & 1969 & 68 & M & Mucinous adenocarcinoma & $\operatorname{pT1}(\mathrm{SM}) \mathrm{NXMX}$ & Radiotherapy + esophagectomy & No recurrence $(7 \mathrm{mo})$ \\
\hline 5 & Sakamoto et al. [12] & 1970 & 64 & M & Adenocarcinoma & pT2NOMO & Esophagectomy & Died (10 mo) \\
\hline 6 & Jernstrom and Brewer [13] & 1970 & 73 & M & Poorly differentiated adenocarcinoma & pT3NOMO & Radiotherapy + esophagectomy & Died (4 mo) \\
\hline 7 & Clemente [14] & 1974 & 53 & M & Adenocarcinoma & pT3 & Esophagectomy & Recurrence (10 mo) \\
\hline 8 & Danoff et al. [15] & 1978 & 43 & M & Poorly differentiated adenocarcinoma & CT4NXMX & Radiotherapy & Died (9 mo) \\
\hline 9 & Goëau-Brissonnière et al. [16] & 1985 & 38 & M & Adenocarcinoma & pT3 & Esophagectomy & No recurrence (31 mo) \\
\hline 10 & Schmidt et al. [17] & 1985 & 37 & M & Adenocarcinoma & pT3 & Esophagectomy & Died (4 mo) \\
\hline 11 & Christensen and Sternberg [18] & 1987 & 52 & M & Poorly differentiated adenocarcinoma & pT2N1M0 & Esophagectomy & Recurrence (25 mo) \\
\hline 12 & Christensen and Sternberg [18] & 1987 & 50 & M & Moderately differentiated adenocarcinoma & pT3N1M0 & Esophagectomy & Unknown \\
\hline 13 & Ishii et al. [19] & 1991 & 66 & M & Moderately differentiated adenocarcinoma & pT3N1M0 & Esophagectomy & No recurrence (20 mo) \\
\hline 14 & Takagi et al. [20] & 1995 & 70 & M & Well- differentiated adenocarcinoma & pT1(SM)NOMO & Esophagectomy & Unknown \\
\hline 15 & Sperling and Grendell [21] & 1995 & 79 & M & Poorlydifferentiated adenocarcinoma & CT4NOMO & Radiotherapy & Unknown \\
\hline 16 & Pai et al. [22] & 1997 & 60 & M & Poorly differentiated adenocarcinoma & pT2NOMO & Surgery/radiochemotherapy & Recurrence (24 mo) \\
\hline 17 & Berkelhammer et al. [23] & 1997 & 71 & M & Moderately differentiated adenocarcinoma & pT1(SM)N1M0 & Esophagectomy & No recurrence (2 yr) \\
\hline 18 & Lauwers et al. [24] & 1998 & 57 & $\mathrm{~F}$ & Moderately differentiated adenocarcinoma & pT3NOMO & Esophagectomy + adjuvant radiotherapy & No recurrence (8 mo) \\
\hline 19 & Klaase et al. [25] & 2001 & 43 & M & Poorly differentiated adenocarcinoma & pT4N1M0 & Esophagectomy + adjuvant radiotherapy & Died (4 mo) \\
\hline 20 & Pech et al. [26] & 2001 & 77 & M & Well-differentiated adenocarcinoma & CT1(SM)NOMO & Endoscopic mucosal resection & No recurrence (1 yr) \\
\hline 21 & Noguchi et al. [27] & 2001 & 73 & M & Well-differentiated adenocarcinoma & CT1(SM)NOMO & Resection of the cervical esophagus & No recurrence $(5 \mathrm{yr})$ \\
\hline 22 & Chatelain et al. [28] & 2002 & 61 & M & Poorly differentiated adenocarcinoma & pT3NXMO & Esophagectomy & Died (15 mo) \\
\hline 23 & Hirayama et al. [29] & 2003 & 77 & $\mathrm{~F}$ & Well-differentiated adenocarcinoma & CT1(M)NOMO & Endoscopic mucosal resection & No recurrence (31 mo) \\
\hline 24 & Balon et al. [30] & 2003 & 61 & M & Adenocarcinoma & pT3NOMO & Esophagectomy & Died (21 mo) \\
\hline 25 & Abe et al. [31] & 2004 & 50 & M & Well-differentiated adenocarcinoma & pT1(SM)NOMO & Esophagectomy & No recurrence $(18 \mathrm{mo})$ \\
\hline 26 & von Rahden et al. [1] & 2005 & 52 & M & Moderately differentiated adenocarcinoma & cT3N1MO & Neoadjuvant chemoradiotherapy + surgery & No recurrence (36 mo) \\
\hline 27 & Alrawi et al. [32] & 2005 & 60 & M & Moderately differentiated adenocarcinoma & pT1(SM)NOMO & Esophagectomy + adjuvant Chemoradiotherapy & No recurrence $(6 \mathrm{yr})$ \\
\hline 28 & Hoshino et al. [33] & 2007 & 74 & M & Papillary adenocarcinoma & pT3NOMO & Esophagectomy & No recurrence $(5 \mathrm{mo})$ \\
\hline 29 & Alagozlu et al. [34] & 2007 & 57 & M & Poorly differentiated adenocarcinoma & CT4N1M0 & None & Died before treatment \\
\hline 30 & Komori et al. [35] & 2010 & 75 & M & Moderately differentiated adenocarcinoma & cT2N1M0 & Esophagectomy & No recurrence (42 mo) \\
\hline 31 & litaka et al. [36] & 2011 & 64 & M & Poorly differentiated adenocarcinoma & pT1(M)NOMO & Esophagectomy & No recurrence $(36 \mathrm{mo})$ \\
\hline 32 & Akanuma et al. [37] & 2013 & 57 & M & Well-differentiated adenocarcinoma & pT2NOMO & Esophagectomy + chemoradiotherapy & No recurrence (4 yr) \\
\hline 33 & Nonaka et al. [38] & 2013 & 74 & M & adenocarcinoma & unknown & Endoscopic submucosal dissection & Unknown \\
\hline 34 & Present case & 2013 & 64 & M & Well-differentiated adenocarcinoma & pT1bNOMO & Esophagectomy & No recurrence (16 mo) \\
\hline
\end{tabular}


severe complications such as bleeding, perforation, stricture, tracheoesophageal fistula formation or webbing [7]. In our patient, it is noteworthy that the area of NEC existed adjacent to the area of tubular adenocarcinoma, which was conterminous with the EGM.

The term mixed exocrine-endocrine carcinoma (MEEC), which was proposed by the World Health Organization (WHO) in its classification system of endocrine tumors, refers to a neoplasm with divergent exocrine and neuroendocrine differentiation [39]. In the latest WHO classification system published in 2010 [2], neuroendocrine neoplasms in the digestive system were reclassified as NET G1, NET G2, NEC and MANEC according to the degree of cellular differentiation and proliferative activity [40]. MEEC/MANEC is distinguished from carcinomas with focal neuroendocrine differentiation by at least two major diagnostic criteria: (1) extension of each component (at least 30\%) and (2) structural features of neuroendocrine components as well-differentiated organoid or solid or diffuse growth patterns [41]. Several cases of MANECs of digestive organs have been reported to be detected in the colon, pancreas, gallbladder, biliary tract, stomach, ampulla, cecum and esophagogastric junction [42-64] (Table 2). Lewin proposed a classification of morphological patterns of the two components in MEEC/MANEC distinguishing (1) truly composite (or mixed) exocrineendocrine tumors with both elements in more or less equal proportions, (2) amphicrine tumors with dual differentiation within the same cell and (3) collision tumors, in which two components are closely juxtaposed but not admixed [65]. According to this classification scheme, our present case was considered to be a composite (mixed) adenoendocrine carcinoma.

The clinical behavior of MANECs is still unclear due to the rarity of these tumors. In 2006, Volante et al. reported that the clinical behavior of MEECs follows that of most aggressive cell types [41]. In the present case, although the well-differentiated tubular adenocarcinoma was confined to the mucosa and submucosa, the NEC components had invaded the submucosa with vascular permeation. Therefore, we think that the pathological features of the NEC component will have a greater influence than those of the tubular adenocarcinoma on the prognosis of this patient.

The optimal treatment for esophageal MANEC has not yet been established. Basically, the standard treatment of patients with esophageal MANEC should be determined in accordance with the treatment recommended for esophageal squamous cell carcinoma. The resectability should be judged on the basis of the preoperative diagnosis, and the decision whether to provide adjuvant therapy should be made on the basis of the postoperative diagnosis. Preoperative chemotherapy is regarded as the standard treatment for patients with stage II/III esophageal squamous cell carcinoma in Japan [66]. In our patient, however, preoperative chemotherapy was not performed, because the preoperative diagnosis was stage IA and the histological diagnosis was not squamous cell carcinoma. Although surgery is the treatment of choice for limited disease of esophageal small cell carcinoma, defined as a tumor confined to a localized region, surgery alone has been found to lead to worse outcomes than adjuvant chemotherapy $[67,68]$. Investigators in several studies have reported that surgery could extend the survival time of patients with limited disease if it was performed as part of multimodal treatment [69,70]. Chemotherapy for esophageal NEC is usually administered according to the recommendations for chemotherapy for small cell lung cancer (SCLC) and usually consists of cisplatin and etoposide $[68,69]$. In our case, there was a choice regarding which adjuvant chemotherapy should be administered because of the pathological features of the NEC components representing vascular permeation. We did not administer adjuvant chemotherapy, however, because of

Table 2 Summary of the cases of mixed adeno(neuro)endocrine carcinoma published in the English-language literature after $2010(N=47)^{a}$

\begin{tabular}{|c|c|c|c|c|c|c|}
\hline Affected organ & Cases & Mean age (yr) & Sex $(M / F)$ & SYN (+/-/unknown) & CGA (+/-/unknown) & CD56 (+/-/unknown) \\
\hline Colon $[6,7]$ & 13 & 71 & $9 / 4$ & $13 / 0 / 0$ & $13 / 0 / 0$ & $0 / 0 / 13$ \\
\hline Pancreas [39-46] & 13 & 69 & $11 / 2$ & $11 / 0 / 2$ & $12 / 0 / 1$ & $0 / 0 / 13$ \\
\hline Gallbladder [47-50] & 8 & 63 & $1 / 7$ & $8 / 0 / 0$ & $7 / 0 / 1$ & $2 / 0 / 6$ \\
\hline Biliary tract $[46,51,52]$ & 6 & 71 & $3 / 3$ & $6 / 0 / 0$ & $5 / 1 / 0$ & $1 / 0 / 3$ \\
\hline Stomach [53-56] & 4 & 71 & $1 / 3$ & $4 / 0 / 0$ & $3 / 1 / 0$ & $2 / 1 / 1$ \\
\hline Ampulla [57] & 1 & 81 & $1 / 0$ & $1 / 0 / 0$ & $1 / 0 / 0$ & $0 / 0 / 1$ \\
\hline Cecum [58] & 1 & 68 & $0 / 1$ & $1 / 0 / 0$ & $1 / 0 / 0$ & $0 / 0 / 1$ \\
\hline Esophagogastric junction [59] & 1 & 68 & $1 / 0$ & $1 / 0 / 0$ & $0 / 0 / 1$ & $0 / 0 / 1$ \\
\hline
\end{tabular}

${ }^{a}$ The cases included in this table are those available in PubMed as of 5 August 2013. We grouped the cases that are expressed as mixed exocrine-endocrine carcinoma, mixed ductal-endocrine carcinoma and mixed acinar-endocrine carcinoma into a single mixed adenoneuroendocrine carcinoma (MANEC) category if they met the World Health Organization classification of endocrine tumors and the paper was published after 2010. We excluded the collision type of MANEC. CGA chromogranin A, SYN synaptophysin. 
the complicated postoperative course resulting from the bilateral recurrent laryngeal nerve injury, the fact that the stage of the disease was IA (pT1bN0M0) and the operation performed had sufficiently high curative potential. However, we think that close follow-up of the patient is mandatory. In addition, Noda et al. suggested the superiority of cisplatin and irinotecan over cisplatin and etoposide for metastatic SCLC [71], and cisplatin and irinotecan is another option for esophageal NEC in Japan.

\section{Conclusion}

Our patient had a rare case of MANEC arising from EGM of the upper thoracic esophagus. To the best of our knowledge, this case report is the first of its kind published in the literature. Because the clinical behavior of esophageal MANEC is poorly understood, further accumulation of similar cases is necessary to clarify the optimal treatment for this disease.

\section{Consent}

Written informed consent was obtained from the patient for publication of this case report and any accompanying images. A copy of the written consent is available for review by the Editor-in-Chief of this journal.

\section{Abbreviations}

EGM: Ectopic gastric mucosa; MANEC: Mixed adenoendocrine carcinoma; NEC: Neuroendocrine carcinoma; SCLC: Small cell lung cancer; WHO: World Health Organization.

\section{Competing interests}

The authors declare that they have no competing interests.

\section{Authors' contributions}

TK wrote the manuscript. SK, SL, SH, HS, MU and HU performed surgery. YO and TF carried out the pathological examination. KS, TF and HU were involved in the final editing. All authors read and approved the final manuscript.

\section{Author details}

${ }^{1}$ Department of Digestive Surgery, Toranomon Hospital, Tokyo, Japan.

2Department of Medical Oncology, Toranomon Hospital, Tokyo, Japan.

${ }^{3}$ Department of Pathology, Toranomon Hospital, Tokyo, Japan.

\section{Received: 26 July 2013 Accepted: 25 August 2013}

Published: 4 September 2013

\section{References}

1. von Rahden BH, Stein HJ, Becker K, Siewert RJ: Esophageal adenocarcinomas in heterotopic gastric mucosa: review and report of a case with complete response to neoadjuvant radiochemotherapy. Dig Surg 2005, 22:107-112.

2. Bosman FT, Carneiro F, Hruban RH, Theise ND (Eds): WHO Classification of Tumors of the Digestive System. Lyon, France: World Health Organization, International Agency for Research on Cancer; 2010.

3. Udagawa H, Akiyama H: Surgical treatment of esophageal cancer: Tokyo experience of the three-field technique. Dis Esophagus 2001, 14:110-114.

4. Edge SB, Byrd DR, Compton CC, Fritz AG, Greene FL, Trotti A (Eds): AJCC Cancer Staging Manual. 7th edition. New York: Springer; 2010.

5. Faintuch J, Shepard KV, Levin B: Adenocarcinoma and other unusual variants of esophageal cancer. Semin Oncol 1984, 11:196-202.

6. Jabbari M, Goresky CA, Lough J, Yaffe C, Daly D, Côté C: The inlet patch: heterotopic gastric mucosa in the upper esophagus. Gastroenterol 1985, 89:352-356
7. Waring JP, Wo JM: Cervical esophageal web caused by an inlet patch of gastric mucosa. South Med J 1997, 90:554-555.

8. Carrie A: Adenocarcinoma of the upper end of the oesophagus arising from ectopic gastric epithelium. Br J Surg 1950, 37:474.

9. Morson BC, Belcher JR: Adenocarcinoma of the oesophagus and ectopic gastric mucosa. Br J Cancer 1952, 6:127-130.

10. Raphael HA, Ellis FH Jr, Dockerty MB: Primary adenocarcinoma of the esophagus: 18-year review and review of literature. Ann Surg 1966, 164:785-796.

11. Davis WM, Goodwin MN Jr, Black HC Jr, Hawk JC: Polypoid adenocarcinoma of the cervical esophagus. Arch Pathol 1969, 88:367-370.

12. Sakamoto G, Nakamura K, Saito K, Sato M, Sugahara T: [Primary adenocarcinoma of the esophagus arising from heterotopic gastric glands] [in Japanese]. Gan No Rinsho 1970, 16:1105-1110.

13. Jernstrom P, Brewer LA 3rd: Primary adenocarcinoma of the midesophagus arising in ectopic gastric mucosa with associated hiatal hernia and reflux esophagitis (Dawson's syndrome). Cancer 1970, 26:1343-1348

14. Clemente C: [A case of adenocarcinoma of the upper third of the esophagus arising on ectopic gastric tissue (author's translation)] [in Italian]. Tumori 1974, 60:17-24.

15. Danoff B, Cooper J, Klein M: Primary adenocarcinoma of the upper oesophagus. Clin Radiol 1978, 29:519-522

16. Goëau-Brissonnière $O$, Hannoun $L$, Huguet $C$ : [Adenocarcinoma of the cervical esophagus. Association with a gastric heterotopia] [in French]. J Chir (Paris) 1985, 122:101-103.

17. Schmidt $H$, Riddell RH, Walther B, Skinner DB, Riemann JF, Groitl H: [Adenocarcinoma of heterotopic gastric mucosa in the proximal esophagus] [in German]. Leber Magen Darm 1985, 15:144-147.

18. Christensen WN, Sternberg SS: Adenocarcinoma of the upper esophagus arising in ectopic gastric mucosa: two case reports and review of the literature. Am J Surg Pathol 1987, 11:397-402.

19. Ishii K, Ota H, Nakayama J, Katsuyama T, Matsuzawa K, Honda T, Akamatsu T: Adenocarcinoma of the cervical oesophagus arising from ectopic gastric mucosa. The histochemical determination of its origin. Virchows Arch A Pathol Anat Histopathol 1991, 419:159-164.

20. Takagi A, Ema Y, Horii S, Morishita M, Miyaishi O, Kino I: Early adenocarcinoma arising from ectopic gastric mucosa in the cervical esophagus. Gastrointest Endosc 1995, 41:167-170.

21. Sperling $\mathrm{RM}$, Grendell $\mathrm{JH}$ : Adenocarcinoma arising in an inlet patch of the esophagus. Am J Gastroenterol 1995, 90:150-152.

22. Pai S, Deshpande R, Naresh KN: Adenocarcinoma of cervical esophagus arising in aberrant gastric mucosa. Indian J Gastroenterol 1997, 16:157-158.

23. Berkelhammer C, Bhagavan M, Templeton A, Raines R, Walloch J: Gastric inlet patch containing submucosally infiltrating adenocarcinoma. J Clin Gastroenterol 1997, 25:678-681.

24. Lauwers GY, Scott GV, Vauthey JN: Adenocarcinoma of the upper esophagus arising in cervical ectopic gastric mucosa: rare evidence of malignant potential of so-called "inlet patch. Dig Dis Sci 1998, 43:901-907.

25. Klaase JM, Lemaire LC, Rauws EA, Offerhaus GJ, van Lanschot JJ: Heterotopic gastric mucosa of the cervical esophagus: a case of highgrade dysplasia treated with argon plasma coagulation and a case of adenocarcinoma. Gastrointest Endosc 2001, 53:101-104.

26. Pech O, May A, Gossner L, Vieth M, Trump F, Stolte M, Ell C: Early stage adenocarcinoma of the esophagus arising in circular heterotopic gastric mucosa treated by endoscopic mucosal resection. Gastrointest Endosc 2001, 54:656-658.

27. Noguchi T, Takeno S, Takahashi Y, Sato T, Uchida Y, Yokoyama S: Primary adenocarcinoma of the cervical esophagus arising from heterotopic gastric mucosa. J Gastroenterol 2001, 36:704-709.

28. Chatelain D, de Lajarte-Thirouard AS, Tiret E, Flejou JF: Adenocarcinoma of the upper esophagus arising in heterotopic gastric mucosa: common pathogenesis with Barrett's adenocarcinoma? Virchows Arch 2002, 441:406-411.

29. Hirayama N, Arima M, Miyazaki S, Shimada H, Okazumi S, Matsubara H, Suzuki T, Ochiai T, Kouzu T: Endoscopic mucosal resection of adenocarcinoma arising in ectopic gastric mucosa in the cervical esophagus: case report. Gastrointest Endosc 2003, 57:263-266.

30. Balon JM, Mariette C, Fabre S, Tiret E, Triboulet JP: [Primary adenocarcinoma of the cervical esophagus arising from heterotopic gastric mucosa] [in French]. Gastroenterol Clin Biol 2003, 27:836-838. 
31. Abe T, Hosokawa M, Kusumi T, Kusano M, Hokari K, Kagaya H, Watanabe A, Fujita M, Sasaki S: Adenocarcinoma arising from ectopic gastric mucosa in the cervical esophagus. Am J Clin Oncol 2004, 27:644-645.

32. Alrawi SJ, Winston J, Tan D, Gibbs J, Loree TR, Hicks W, Rigual N, Lorè JM Jr: Primary adenocarcinoma of cervical esophagus. J Exp Clin Cancer Res 2005, 24:325-330.

33. Hoshino A, Otuka Y, Nara S, Harihara Y, Konishi T: A case of primary adenocarcinoma of the cervical esophagus arising from the ectopic gastric mucosa. Esophagus 2007, 4:83-86.

34. Alagozlu H, Ergun M, Cindoruk M, Unal S, Dumlu S, Poyraz A, Dursun A: The rare presentations of a large polyp and an esophageal carcinoma in heterotropic gastric mucosa: a case series. J Med Case Rep 2007, $1: 127$

35. Komori S, Osada S, Tanaka Y, Takahashi T, Nagao N, Yamaguchi K, Asano N, Yoshida K: A case of esophageal adenocarcinoma arising from the ectopic gastric mucosa in the thoracic esophagus. Rare Tumors 2010, 2:e5.

36. litaka D, Fujiwara $H$, Shiozaki A, Kubota T, Ando T, Murayama Y, Komatsu S, Kuriu Y, Ikoma H, Nakanishi M, Ichikawa D, Okamoto K, Ochiai T, Kokuba Y, Otsuji E: Double primary cancer of the esophagus consisting of ectopic gastric mucosa-derived adenocarcinoma and squamous cell carcinoma: a first case report. Esophagus 2011, 8:303-309.

37. Akanuma N, Hoshino I, Akutsu Y, Shuto K, Shiratori T, Kono T, Uesato M, Sato A, Isozaki Y, Maruyama T, Takeshita N, Matsubara H: Primary esophageal adenocarcinoma arising from heterotopic gastric mucosa: report of a case. Surg Today 2013, 43:446-451.

38. Nonaka K, Watanabe M, Yuruki H, Okuda A, Sakurai K, Iyama K, Sasaki Y: Narrow band imaging of adenocarcinoma arising from ectopic gastric mucosa in the upper esophagus. Endoscopy 2013, 45(Suppl 2 UCTN):E112-E113.

39. Solcia E, Klöppel G, Sobin LH, Capella C, DeLellis RA, Heitz PU, Horvath E, Kovacs K, Lack E, Lloyd RV, Rosai J, Scheithauer BW: Histological Typing of Endocrine Tumours (WHO International Histological Classification of Tumours series). 2nd edition. New York: Springer Verlag; 2000:56-70.

40. Rindi G, Arnold R, Bosman FT: Nomenclature and classification of neuroendocrine neoplasms of the digestive system. In WHO Classification of Tumors of the Digestive System. Edited by Bosman FT, Carneiro F, Hruban $\mathrm{RH}$, Theise ND. Lyon, France: World Health Organization, International Agency for Research on Cancer; 2010:13-14.

41. Volante M, Rindi G, Papotti M: The grey zone between pure (neuro) endocrine and non-(neuro)endocrine tumours: a comment on concepts and classification of mixed exocrine-endocrine neoplasms. Virchows Arch 2006, 449:499-506

42. Marando A, Dainese E, La Rosa S, Capella C: Images in endocrine pathology: oncocytic differentiation in a mixed adenoneuroendocrine carcinoma of the colon. Endocr Pathol 2013, 24:54-56.

43. La Rosa S, Marando A, Furlan D, Sahnane N, Capella C: Colorectal poorly differentiated neuroendocrine carcinomas and mixed adenoneuroendocrine carcinomas: insights into the diagnostic immunophenotype, assessment of methylation profile, and search for prognostic markers. Am J Surg Pathol 2012, 36:601-611.

44. Kobayashi S, Asakura T, Ohike N, Enomoto T, Sakurai J, Koizumi S, Watanabe T, Nakano $H$, Otsubo T: Mixed acinar-endocrine carcinoma of the pancreas with intraductal growth into the main pancreatic duct: report of a case. Surg Today 2010, 40:380-384

45. Chung WJ, Byun JH, Lee SS, Lee MG: Imaging findings in a case of mixed acinar-endocrine carcinoma of the pancreas. Korean J Radiol 2010, 11:378-381.

46. Araki K, Shimura T, Kobayashi T, Saito K, Wada W, Sasaki S, Suzuki H, Kashiwabara K, Nakajima T, Kuwano H: Mixed ductal-endocrine carcinoma of the pancreas occurring as a double cancer: report of a case. Int Surg 2011, 96:153-158.

47. Hirano H, Terada N, Yamada N, Yamanegi Y, Oyama H, Nishigami T, Nakasho $\mathrm{K}$ : A case of mixed ductal-endocrine carcinoma of the pancreas. Med Mol Morphol 2011, 44:58-62.

48. Lennerz JK, Fernandez-Del Castillo C, Pitman MB: Mixed ductal-endocrine carcinoma of the pancreas metastatic to the liver. Pancreas 2011, 40:319-321.

49. Ahmad Z, Mumtaz S, Fatima S, Qureshi A: Mixed ductal-endocrine carcinoma of pancreas. BMJ Case Rep, 2011:bcr0220113861. doi:10.1136/ bcr.02.2011.3861.
50. Sullivan PS, Clebanoff $J$, Hirschowitz SL: Hints to the diagnosis of mixed acinar-endocrine carcinoma on pancreatic fine-needle aspiration: avoiding a potential diagnostic pitfall. Acta Cytol 2013, 57:296-302.

51. Yu R, Jih L, Zhai J, Nissen NN, Colquhoun S, Wolin E, Dhall D: Mixed acinarendocrine carcinoma of the pancreas: new clinical and pathological features in a contemporary series. Pancreas 2013, 42:429-435.

52. Harada K, Sato Y, Ikeda H, Maylee H, Igarashi S, Okamura A, Masuda S, Nakanuma Y: Clinicopathologic study of mixed adenoneuroendocrine carcinomas of hepatobiliary organs. Virchows Arch 2012, 460:281-289.

53. Paniz Mondolfi AE, Slova D, Fan W, Attiyeh FF, Afthinos J, Reidy J, Pang $Y$, Theise ND: Mixed adenoneuroendocrine carcinoma (MANEC) of the gallbladder: a possible stem cell tumor? Pathol Int 2011, 61:608-614.

54. Song W, Chen W, Zhang S, Peng J, He Y: Successful treatment of gallbladder mixed adenoneuroendocrine carcinoma with neo-adjuvant chemotherapy. Diagn Pathol 2012, 27:7-163.

55. Shintaku M, Kataoka K, Kawabata K: Mixed adenoneuroendocrine carcinoma of the gallbladder with squamous cell carcinomatous and osteosarcomatous differentiation: report of a case. Pathol Int 2013, 63:113-119.

56. Onishi I, Kitagawa H, Harada K, Maruzen S, Sakai S, Makino I, Hayashi H, Nakagawara H, Tajima H, Takamura H, Tani T, Kayahara M, Ikeda H, Ohta T, Nakanuma Y: Intraductal papillary neoplasm of the bile duct accompanying biliary mixed adenoneuroendocrine carcinoma. World J Gastroenterol 2013, 28:3161-3164.

57. Linder R, Dorfman T, Ben-Ishay O, Kakiashvili E, Velodavsky E, Kluger Y: Mixed neuroendocrine tumor of the common bile duct. JOP 2013, 14:71-73.

58. Kim TY, Chae HD: Composite neuroendocrine carcinoma with adenocarcinoma of the stomach misdiagnosed as a giant submucosal tumor. J Gastric Cancer 2011, 11:126-130.

59. Mitsutsuji M, Okamura A: A resected case of metachronous liver metastasis from mixed adenoneuroendocrine carcinoma of the stomach. Nihon Shokakibyo Gakkai Zasshi 2011, 108:1910-1915.

60. Pericleous M, Toumpanakis C, Lumgair H, Caplin ME, Morgan-Rowe L, Clark I, Luong TV: Gastric mixed adenoneuroendocrine carcinoma with a trilineage cell differentiation: case report and review of the literature. Case Rep Oncol 2012, 5:313-319.

61. Lee JH, Kim HW, Kang DH, Choi CW, Park SB, Kim SH: A gastric composite tumor with an adenocarcinoma and a neuroendocrine carcinoma: a case report. Clin Endosc 2013, 46:280-283.

62. Vilardell F, Velasco A, Cuevas D, Olsina JJ, Matias-Guiu X: Composite papillary intestinal-type adenocarcinoma/poorly differentiated neuroendocrine carcinoma of the ampulla of Vater. J Clin Pathol 2011, 64:174-177.

63. Jain A, Singla S, Jagdeesh KS, Vishnumurthy HY: Mixed adenoneuroendocrine carcinoma of cecum: a rare entity. J Clin Imaging Sci 2013, 28:3-10.

64. Veits L, Lang-Schwarz C, Volkholz H, Falkeis C, Vieth M, Schulz H: Mixed adenoneuroendocrine carcinoma (MANEC) of the esophagogastric junction predominantly consisting of poorly differentiated neuroendocrine carcinoma. Endoscopy 2013, 45:E16-E17.

65. Lewin K: Carcinoid tumors and the mixed (composite) glandularendocrine cell carcinomas. Am J Surg Pathol 1987, 11:71-86.

66. Ando $N$, Kato $H$, Igaki $H$, Shinoda M, Ozawa $S$, Shimizu H, Nakamura T, Yabusaki H, Aoyama N, Kurita A, Ikeda K, Kanda T, Tsujinaka T, Nakamura K, Fukuda $\mathrm{H}$ : A randomized trial comparing postoperative adjuvant chemotherapy with cisplatin and 5-fluorouracil versus preoperative chemotherapy for localized advanced squamous cell carcinoma of the thoracic esophagus (JCOG9907). Ann Surg Oncol 2012, 19:68-74.

67. Casas F, Ferrer F, Farrús B, Casals J, Biete A: Primary small cell carcinoma of the esophagus: a review of the literature with emphasis on therapy and prognosis. Cancer 1997, 80:1366-1372.

68. Kubota K, Okada A, Kuroda J, Yoshida M, Origuchi N, Ohta K, Itabashi M, Osamura Y, Kitajima M: Neuroendocrine carcinoma of the esophagus: report of a case and review of the literature. Open J Gastroenterol 2012 , 2:85-90.

69. Brenner B, Tang LH, Klimstra DS, Kelsen DP: Small-cell carcinomas of the gastrointestinal tract: a review. J Clin Oncol 2004, 22:2730-2739.

70. Maru DM, Khurana H, Rashid A, Correa AM, Anandasabapathy S, Krishnan S, Komaki R, Ajani JA, Swisher SG, Hofstetter WL: Retrospective study of 
clinicopathologic features and prognosis of high-grade neuroendocrine carcinoma of the esophagus. Am J Surg Pathol 2008, 32:1404-1411.

71. Noda K, Nishiwaki Y, Kawahara M, Negoro S, Sugiura T, Yokoyama A,

Fukuoka M, Mori K, Watanabe K, Tamura T, Yamamoto S, Saijo N, Japan

Clinical Oncology Group: Irinotecan plus cisplatin compared with

etoposide plus cisplatin for extensive small-cell lung cancer. N Engl

$J$ Med 2002, 346:85-91.

doi:10.1186/1477-7819-11-218

Cite this article as: Kitajima et al:: Mixed adeno(neuro)endocrine

carcinoma arising from the ectopic gastric mucosa of the upper

thoracic esophagus. World Journal of Surgical Oncology 2013 11:218.

\section{Submit your next manuscript to BioMed Central and take full advantage of:}

- Convenient online submission

- Thorough peer review

- No space constraints or color figure charges

- Immediate publication on acceptance

- Inclusion in PubMed, CAS, Scopus and Google Scholar

- Research which is freely available for redistribution 